\title{
Article
}

\section{Cold storage of 'Palmer' mangoes sorted based on dry matter content using portable near infrared (VIS-NIR) spectrometer}

Santos Neto, João Paixão dos, Leite, Gustavo Walace Pacheco, Oliveira, Gabriele da Silva, Cunha Júnior, Luís Carlos, Gratão, Priscila Lupino, Medeiros-De-morais, Camilo De lelis and Teixeira, Gustavo Henrique de Almeida

Available at http://clok.uclan.ac.uk/22728/

Santos Neto, João Paixão dos, Leite, Gustavo Walace Pacheco, Oliveira, Gabriele da Silva, Cunha Júnior, Luís Carlos, Gratão, Priscila Lupino, MedeirosDe-morais, Camilo De lelis ORCID: 0000-0003-2573-787X and Teixeira, Gustavo Henrique de Almeida (2018) Cold storage of 'Palmer' mangoes sorted based on dry matter content using portable near infrared (VIS-NIR) spectrometer. Journal of Food Processing and Preservation, 42 (6). e13644. ISSN 0145-8892

It is advisable to refer to the publisher's version if you intend to cite from the work. http://dx.doi.org/10.1111/jfpp.13644

For more information about UCLan's research in this area go to http://www.uclan.ac.uk/researchgroups/ and search for <name of research Group>.

For information about Research generally at UCLan please go to http://www.uclan.ac.uk/research/

All outputs in CLoK are protected by Intellectual Property Rights law, including Copyright law. Copyright, IPR and Moral Rights for the works on this site are retained by the individual authors and/or other copyright owners. Terms and conditions for use of this material are defined in the policies page. 
1 Cold storage of 'Palmer' mangoes sorted based on dry matter content using portable 2 near infrared (VIS-NIR) spectrometer

3

4 João Paixão dos Santos Neto ${ }^{\mathrm{a}}$, Gustavo Walace Pacheco Leite ${ }^{\mathrm{a}}$, Gabriele da Silva Oliveira ${ }^{\text {a }}$,

5 Luís Carlos Cunha Júnior ${ }^{\mathrm{b}}$, Priscila Lupino Gratão ${ }^{\mathrm{a}}$, Camilo de Lelis Medeiros de Morais ${ }^{\mathrm{c}}$,

6 Gustavo Henrique de Almeida Teixeira ${ }^{\mathrm{a}}$ *

7

8 anniversidade Estadual Paulista (UNESP), Faculdade de Ciências Agrárias e Veterinárias 9 (FCAV), Campus de Jaboticabal. Via de acesso Prof. Paulo Donato Castellane s/n, 10 Jaboticabal - SP, Brazil. CEP: 14.870-900.

11 bUniversidade Federal de Goiás (UFG), Escola de Agronomia (EA), Setor de Horticultura.

12 Rodovia Goiânia Nova Veneza, km 0, Campus Samambaia. Caixa Postal 131, Goiânia - GO, 13 Brazil. CEP: 74.690-900.

14 'University of Central Lancashire, School of Pharmacy and Biomedical Sciences, Preston, 15 Lancashire, PR1 2HE, United Kingdom.

*Corresponding author: Tel.: +55 16 3209-7532. E-mail address: gustavo@ @cav.unesp.br

19 Abstract

The objective of this study was to use dry matter (DM) calibration models to sort

21 'Palmer' mangoes prior cold storage and to evaluate the physiological and chemical changes 
during the storage period. PLS model developed with fruit from 2015/2016 season was not adequate to predict DM content in fruit from 2016/2017 (not adjusted $\mathrm{R}^{2}$ ). Therefore, VISNIR spectra from 2016/2017 season were incorporated into data set and a new model was developed (RMSE $\mathrm{cv}_{\mathrm{cv}}$ of $10.5 \mathrm{~g} \cdot \mathrm{kg}^{-1}, \mathrm{R}_{\mathrm{P}}^{2}$ of 0.75$)$. With the new model, 'Palmer' mangoes were sorted into two maturity stages (150 g. $\mathrm{kg}^{-1}$ and $\left.110 \mathrm{~g} \cdot \mathrm{kg}^{-1}\right)$ which resulted in quality differences mainly in relation to DM and SSC. Portable VIS/NIR spectrometer can be used to sort fruit according to maturity stages based on DM content and this classification affect fruit quality during cold storage as fruit with higher DM (150 g. $\left.\mathrm{kg}^{-1}\right)$ presented better quality than fruit with lower DM (110 g. $\left.\mathrm{kg}^{-1}\right)$.

Keywords: Mangifera indica L., chemometrics, PLS, SSC, DM, SVR.

\section{Practical applications}

(1)

Although results can be found regarding the use of portable NIR spectrometers to estimate maturity in mango fruit, there are no studies stating the use of this method to sort fruit prior cold storage. Our results highlight that portable VIS/NIR spectrometer can be used to sort fruit according to maturity stages based on dry matter (DM) content and this classification affects fruit quality during cold storage as fruit with higher DM (150 g.kg $\left.{ }^{-1}\right)$ presented better quality than fruit with lower DM $\left(110 \mathrm{~g}_{\mathrm{kg}}{ }^{-1}\right)$ at the end of the storage period.

\section{Introduction}


Non-destructive methods have long been suggested as a means to evaluate fruit quality and near infrared (NIR) spectroscopy is one of the analytical techniques that stand out (Abbott, 1999). Therefore, many studies can be found with bench top and/or on-line NIR spectrometers estimating soluble solids content (SSC), dry matter content (DM), titratable acidity (TA), firmness, starch content, and other quality parameters in mango fruit (Schmilovitch et al., 2000; Saranwong et al., 2001; Mahayothee et al., 2004; Saranwong et al., 2004; Delwiche et al., 2008; Valente et al., 2009).

Classic studies on portable NIR spectrometers to estimate quality parameters in mangoes were reported by Mahayothee et al. (2004), Saranwong et al. (2004), and Subedi et al. (2007). More recently, a portable Luminar 5030 NIR was used by Jha et al. (2014) to assess a maturity index estimated based on soluble solids content (SSC), dry matter (DM) and titratable acidity (TA) in seven mango varieties. Rungpichayapichet et al. (2016) used a portable VIS/NIR photo-diode array spectrometer (HandySpec Field 1000, tec5AG) to study mango fruit quality and maturity and good results were reported for SSC prediction (standard error of prediction (SEP) of $1.2 \%$ and a correlation coefficient $\left(\mathrm{R}^{2}\right)$ of 0.90 ), for firmness prediction (SEP of $4.22 \mathrm{~N}$ and $\mathrm{R}^{2}$ of 0.82 ), and for TA prediction (SEP of $0.38 \%$ and $\mathrm{R}^{2}$ of 0.74). Marques et al. (2016) studying 'Tommy Atkins' mangoes used a portable MicroNIR 1700 to predict SSC, DM, TA, and firmness with low root mean square error of prediction (RMSEP), $0.92{ }^{\circ}$ Brix, $0.51 \%, 0.17 \%$, and $12.2 \mathrm{~N}$, respectively. Santos Neto et al. (2017) reported for the first time the use of a portable F-750 to predict DM in 'Palmer' mango with good results (root mean square error of cross validation (RMSE $\mathrm{Cv}_{\mathrm{Cv}}$ ) of $8.3 \mathrm{~g} \cdot \mathrm{kg}^{-1}$ and $\mathrm{RMSE}_{\mathrm{cv}}$ of $8.8 \mathrm{~g} . \mathrm{kg}^{-1}$ with a $\mathrm{R}_{\mathrm{c}}^{2}$ of 0.86 and $\mathrm{R}_{\mathrm{cv}}^{2}$ of 0.84 ). Nordey et al. (2017) reported that 'Cogshall' mango quality varies with pre and post-harvest practices, and the differences in SSC, DM, hue angle, TA and firmness were determined using a portable LABSPEC 2500 NIR spectrometer. More robust results were reported by Walsh \& Subedi (2016) with portable VIS/NIR 
spectrometer used to in field DM content in mango fruit of different varieties with a RMSE $E_{C V}$ of $0.68 \%$ and a $\mathrm{R}^{2}$ of 0.94 .

Although results can be found regarding the use of portable NIR spectrometers to estimate maturity in mango fruit, there are no studies stating the use of this method to sort fruit prior cold storage. Mango maturity stage estimation by means of portable NIR spectroscopy should be accurate as maturity plays an important role during cold storage as the susceptibility to chilling injury varies according to mango maturity stages (Medlicott et al., 1988; Kader, 2003). According to Mohammed \& Brecht (2002), the symptoms of chilling injury in mangoes are related to skin discoloration (grayish scald-like), skin pitting, uneven ripening, reductions in the level of carotenoids, aroma, and flavor during ripening. These authors reported that immature mango fruit, characterized by having shoulders below the pedicel insertion, showed chilling injury symptoms after 18 days at $5^{\circ} \mathrm{C}$. According to Brecht \& Yahia (2009), mature-green mangoes stored under low temperature $\left(0^{\circ} \mathrm{C}\right)$ for one day or for few weeks at temperatures bellow $12^{\circ} \mathrm{C}$ can develop chilling injury. On the other hand, fully ripe fruit can be stored at $8-10^{\circ} \mathrm{C}$ without showing such injury (Paull \& Duarte, 2011). Mango is a climacteric and perishable fruit which ripen quickly at ambient temperature and their quality can only be maintained for 8 days under these conditions (Kader, 2003). Cold storage can be used to extend the shelf-life of mangoes for up to 16 days, but due to the development of chilling injury at temperatures below $13^{\circ} \mathrm{C}$ (Miltra \& Baldwin, 1997), the temperatures used to transport mangoes are not low enough to delay ripening, decay and senescence (Brecht \& Yahia, 2009).

Therefore as it is essential to develop standard maturity indices for mangoes for a particular cultivar, growing region and for local or export markets (Yahia, 2011), and the importance of an accurate maturity stage determination prior cold storage, the objective of this study was to use the calibration models for DM content prediction of 'Palmer' mango 
94

95

developed by Santos Neto et al. (2017) to sort mangoes prior cold storage and to evaluate the physiological and chemical changes during the storage period of 14 days similar to maritime shipment from Brazil to Europe.

\section{Material and methods}

\subsection{Plant material}

'Palmer' mango (Mangifera indica L.) fruit were harvested in a commercial orchard located at Cândido Rodrigues (2119'21" South, 48³8'2” West, 671 m altitude), São Paulo State, Brazil. The panicles were marketed when mango trees were in full bloom and fruit were harvest after 139 days after bloom (DAB).

\subsection{Spectra acquisition using portable NIR spectrometer}

Prior to the cold storage, 20 fruit were harvest (125 DAB) and NIR spectra were collected according to the methodology described by Subedi et al. (2007) and Santos Neto et al. (2017) using a portable F-750 (Felix Instruments, Washington, USA), on the wavelength range of 310 to $1,100 \mathrm{~nm}$, using interactance as optic configuration and a resolution of 8-13 nm. The light source was a halogen lamp.

The dry matter (DM) content was determined as reported by Santos Neto et al. (2017) and the PLS model described by these authors was used to predict the maturity stages based on DM content. A second harvest prior to the cold storage experiment was carried out (132 DAB) and 20 more fruit were evaluated according to the previous description. The NIR spectra of both prior harvests (125 and $132 \mathrm{DAB})$ were incorporated into the data set and a new PLS model was developed using full cross validation on the spectral range of 699-981 nm without applying any pre-processing according to Santos Neto et al. (2017). 
For the cold storage experiment, a total of 430 fruit were harvested at $139 \mathrm{DAB}$, the

117

NIR spectra were collected using the portable F-750 NIR spectrometer, and the maturity stages were determined by DM prediction using the new PLS model. Following the recommendations that mango fruit have to be harvested with 150 g. $\mathrm{kg}^{-1} \mathrm{DM}$ (Walsh, 2016), the fruit were sorted into two classes, as such: $i$. fruit with $150 \mathrm{~g} \cdot \mathrm{kg}^{-1} \mathrm{DM}$, and ii. fruit with 110 g.kg-1 DM (commonly observed in export mangoes in São Paulo State, Brazil).

\subsection{Maturity stage prediction - chemometrics}

The NIR spectra obtained in the first harvest (125 DAB) was used as a prediction set applying the DM calibration model developed by Santos Neto et al. (2017). The Unscrambler version 10.3 (Camo, Oslo, Norway) was used for data analysis and the prediction performance was evaluated according to the coefficient of determination $\left(\mathrm{R}^{2}\right)$ and the root mean square error of prediction (RMSEP) as stated by Golic \& Walsh (2006), and Nicolaï et al. (2007). As the DM prediction results were not satisfactory [high RMSEP and SEP values, and not adjusted (NA) $\mathrm{R}_{2}$ ], the NIR spectra of the first harvest was incorporated into the data set and a new full cross validation model was developed using a partial least squares (PLS) regression and support vector regression (SVR). The performance of the new model was evaluated based on the coefficient of determination of cross validation $\left(\mathrm{R}_{\mathrm{CV}}{ }^{2}\right)$, the root mean square error of cross validation $\left(\mathrm{RMSE}_{\mathrm{CV}}\right)$, and RMSEP. To evaluate the new model, a second harvest was carried out (132 DAB) and the prediction procedure repeated. Again, the DM prediction was not satisfactory and the NIR spectra of the second harvest was incorporated into the data set and a new PLS model for DM prediction was developed. Finally, the new model with NIR spectra from 2016 and 2017 was used to predict the maturity stages based on DM content of the 430 fruit used in the cold storage experiment. The descriptive statistics for the two maturity stages can be seen in Table 1 . 


\subsection{Reference analysis - dry matter}

On the same location where the VIS-NIR spectra were obtained, samples of $27 \mathrm{~mm}$ in diameter and with $10 \mathrm{~mm}$ of depth were collected for dry matter (DM) determination (Subedi et al., 2007). Mango epidermis (1-2 mm thick) was removed using a potato peeler and the DM content determined by the samples weight loss after 48 hours of oven dry at $105{ }^{\circ} \mathrm{C}$ (Santos Neto et al., 2017).

\subsection{Cold storage}

Due to mango sensibility to temperatures below $13{ }^{\circ} \mathrm{C}$ (Miltra \& Baldwin, 1997), 'Palmer' mangoes were stored in a cold room at $12.3^{ \pm} 0.4{ }^{\circ} \mathrm{C}$ and $69.9^{ \pm} 4.1 \% \mathrm{RH}$ for up to 14 days. After this period the fruit were transferred to ambient conditions $\left(21.6^{ \pm} 4.2{ }^{\circ} \mathrm{C}\right.$ and $67.6 \pm 4.5 \% \mathrm{RH}$ ) for 7 days simulating the commercialization period.

From a total of 430 harvested fruit, 66 were sorted as containing 150 g.kg-1 DM and 70 as containing 110 g. $\mathrm{kg}^{-1} \mathrm{DM}$ (Table 1). The experiment was set up in a completely randomized design (CRD) in a factorial arrangement 2 (maturity stages: 150 g.kg-1 $\mathrm{DM}$ and 110 g.kg-1 DM) x 3 (withdraws: 0, 7, 14 days) with 10 repetitions (fruit). For the fruit transferred to ambient it was used a CRD with 2 treatments (maturity stages: 150 g.kg ${ }^{-1} \mathrm{DM}$ and 110 g. $\left.\mathrm{kg}^{-1} \mathrm{DM}\right)$ and 5 repetitions (fruit).

\subsection{Quality evaluations}

\subsubsection{Respiration}

A respirometer was used for the respiration rate $\left(\mathrm{mg} \cdot \mathrm{CO}_{2} \cdot \mathrm{kg}^{-1} \cdot \mathrm{h}^{-1}\right)$ determination. Three fruit from each treatment were individually set into a hermetical plastic jar and air was pumped through the jars. The air passed through a 200 g.kg-1 (w/v) calcium hydroxide $\left(\mathrm{CaO}_{2}\right)$ solution, and through a $50 \mathrm{~g} \cdot \mathrm{kg}^{-1}(\mathrm{w} / \mathrm{v})$ potassium permanganate $\left(\mathrm{KMnO}_{4}\right)$ solution prior 
163

164

entering the jars containing the fruit. The air passed through the jars and the outlet tube was let inside a $0.1 \mathrm{~N}$ potassium hydroxide $(\mathrm{KOH})$ solution for one hour. Before and after this period the $\mathrm{CO}_{2}$ content absorbed by the $\mathrm{KOH}$ solution was determined by titratation and the respiratory rate calculated according to Bleinroth et al. (1976), as such:

$$
\frac{2,2 \times(B-A) \times V_{1}}{P \times T \times V_{2}}
$$

Where: $\mathrm{B}$ is the volume $(\mathrm{mL})$ of $\mathrm{HCl}$ before one hour, $\mathrm{A}$ is the volume $(\mathrm{mL})$ of $\mathrm{HCl}$ after one hour, $\mathrm{V}_{1}$ is the total volume of $\mathrm{KOH}(\mathrm{mL}), \mathrm{V}_{2}$ is the volume of $\mathrm{KOH}(\mathrm{mL})$ used in the titration, $\mathrm{P}$ is the fruit mass $(\mathrm{kg}), \mathrm{T}$ is the time (hour), and 2.2 is the factor of $\mathrm{CO}_{2}(44 / 2)$ equivalent times the $\mathrm{HCl}(0.1 \mathrm{~N})$ volume.

This analysis was carried out each two days during cold storage and after transfer to fruit to ambient condition.

\subsubsection{Fresh weight loss}

Fresh fruit weight loss (FWL) was determined based on the difference in fruit mass from the different withdrawals $(0,7,14$ days, and after 7 days in ambient) with 10 repetitions (fruit) per treatment. The fruit mass was determined using a semi-analytical balance with a precision of $0.01 \mathrm{~g}$ (Marte, model AS 2000, São Paulo, Brazil).

\subsubsection{Colour}

Mango skin colour was determined using a Minolta colorimeter (Model CR-400, Minolta Corp., Osaka, Japan) with an $8 \mathrm{~mm}$ aperture. The $\mathrm{L}^{*}, \mathrm{a}^{*}, \mathrm{~b}^{*}$ color parameters were used to obtain the luminosity $\left(\mathrm{L}^{*}\right)$, chromaticity and hue angle (McGuire, 1992). Two readings were taken from each fruit on opposite sides of the equatorial region. 
Fruit firmness determination was carried were on opposite sides of the equatorial

186

187 region of each mango after removing the skin according to Watkins \& Harman (1981). An Effegi Fruit Tester penetrometer (Bishop FT 327 Penetrometer, Alfonsine, Italy) with an 8.0 $\mathrm{mm}$ tip was used and the results were expressed in Newton $(\mathrm{N})$.

\subsubsection{Physico-chemical analysis}

The pulp of the mango fruit from the different withdrawals $(0,7,14$ days, and after 7 days in ambient) was homogenized and used to soluble solids content (SSC) determination using a digital refratometer PR-101 $\alpha$ (Atago, Tokyo, Japan) according to the AOAC method proc. 920.151 (AOAC, 1997). Titatrable acidity (TA) determination was carried out using AOAC method 932-12 (AOAC, 1997), which allowed the calculus of the SSC/TA ratio. The pH was also determined (AOAC, 1997-proc 945-27) and the vitamin C content was determined using Tillmans method (Strohecker \& Henning, 1967) with the results expressed as $\mathrm{g} \cdot \mathrm{kg}^{-1}$.

\subsubsection{Sensory evaluation}

The external and internal appearance of the mango fruit were evaluated by a untrained sensory panel $(n=20)$ using a hedonic scale of 9 points, as such: 9 - like extremely, 8 - like very much, 7 - like moderately, 6 - like slightly, 5 - neither like nor dislike, 4 - dislike slightly, 3 - dislike moderately, 2 - dislike very much, and 1 - dislike extremely. This evaluation was carried out in the different withdrawals $(0,7,14$ days, and after 7 days in ambient) (Dutcosky, 2013).

\subsection{Statistical analysis}

The data was subjected to analysis of variance (ANOVA) using the PROC MIXED procedure of SAS (1999) and the means compared using Tukey's test with 5\% probability. 
The data of the fruit transfer to ambient temperature was subjected to ANOVA using the GLM procedure of SAS (1999) and the means compared using Tukey's test with 5\% 210 probability.

\section{Results and discussion}

\subsection{Maturity stage prediction}

The determination of 'Palmer' mango maturity stage using VIS-NIR portable spectrometer was carried out based on our previous study (Santos Neto et al., 2017) with fruit harvested in the 2015/2016 season. Although good results were reported, RMSE $\mathrm{C}_{\mathrm{C}}$ of $8.3 \mathrm{~g} . \mathrm{kg}^{-1}$ and $\mathrm{RMSE}_{\mathrm{cv}}$ of 8.8 g.kg ${ }^{-1}$ with a $\mathrm{R}_{\mathrm{c}}^{2}$ of 0.86 and $\mathrm{R}_{\mathrm{cv}}^{2}$ of 0.84 (Santos Neto et al., 2017), Peirs et al. (2002) stated that the seasonal variability is an important source of variation and must be taken into account to develop robust prediction models. Therefore, prior to the cold storage, 20 fruit were harvested from the 2016/2017 season and mango maturity was predicted based on DM content using Santos Neto et al. (2017) results (Figure 1A).

Based on the prediction performance the PLS model developed with fruit from $2015 / 2016$ season, it was not possible to predict DM in fruit from $2016 / 2017$ as the $\mathrm{R}^{2}$ was not adjusted (NA) and the RMSEP and SEP values sharply increased to $55.6{\mathrm{~g} . \mathrm{kg}^{-1}}^{-}$and 109.3 g.kg-1 ${ }^{-1}$ respectively (Figure 1A). These results are in agreement with Peirs et al. (2002), which means, seasonal variability is an important source of variation and have to be taken into consideration in developing calibration models. Both seasons were quite similar in terms of average temperatures. However, in 2015/2016 it was observed higher precipitations (192.3 $\mathrm{mm}$ ) in relation to $2016 / 2017(116.3 \mathrm{~mm})$, this might have affected the sunlight hours and relative humidity (Table 2). Overcast weather conditions resulted in less sunlight and reduce fruit development rates. The differences in sunlight also affect photosynthesis and DM 
accumulation, which might have contributed for the differences found between fruits from different harvest seasons.

To solve the lack of robustness, the VIS-NIR spectra from the 20 fruit harvested 125 DAB were incorporated into the calibration set obtained in 2015/2016 and a new PLS model was developed, similar to Santos Neto et al. (2017), Figure 1B. With this procedure it was observed that the PLS model performance was inferior than what was reported in 2015/2016, which means the RMSE $E_{C}$ increased from 8.3 g. $\mathrm{kg}^{-1}$ to $12.1 \mathrm{~g} \cdot \mathrm{kg}^{-1}, \mathrm{RMSE}_{\mathrm{cv}}$ from $8.8 \mathrm{~g} \cdot \mathrm{kg}^{-1}$ to $12.6 \mathrm{~g} . \mathrm{kg}^{-1}$, and $\mathrm{R}_{\mathrm{c}}^{2}$ value reduced from 0.86 to 0.67 (Figure $1 \mathrm{~B}$ ).

Similarly, a second harvest was carried out at 132 DAB prior mango cold storage and the maturity stages were predicted using the new PLS model (Figure 2A). However, even incorporating VIS-NIR spectra from 2016/2017 into the data set, the new PLS model did not perform well and the DM content could not be accurately predicted as the $\mathrm{R}^{2}$ was not adjusted (NA) and the RMSEP and SEP values increased to 32.5 g.kg ${ }^{-1}$ and 61.1 g.kg ${ }^{-1}$, respectively (Figure 1A). These values were lower than when the PLS model of 2015/2016 was firstly used to predict the DM content of the fruit from 2016/2017, though. Therefore, the strategy of incorporating new sources of variability improves the prediction capability and accuracy (Nicolaï et al., 2007; Pasquini, 2003). However, the RMSEP and SEP values were too high and the VIS-NIR spectra from the second harvest was also incorporated into the data set and a new PLS model was developed following the same procedure previously described (Figure 2B). By incorporating the VIS-NIR spectra of the second harvest from 2016/2017 season it was observed a slight better performance as the $\mathrm{RMSE}_{\mathrm{C}}$ and $\mathrm{RMSE}_{\mathrm{cv}}$ values reduced from 12.1 g. $\mathrm{kg}^{-1}$ to $10 \mathrm{~g} . \mathrm{kg}^{-1}$ and from 12.6 g. $\mathrm{kg}^{-1}$ to $10.5 \mathrm{~g} . \mathrm{kg}^{-1}$, respectively (Figure $1 \mathrm{~B}, 2 \mathrm{~B}$ ). The $\mathrm{R}_{\mathrm{c}}^{2}$ and $\mathrm{R}_{\mathrm{P}}^{2}$ increased to 0.77 and 0.75 , respectively (Figure $1 \mathrm{~B}, 2 \mathrm{~B}$ ). 

'Palmer' mangoes harvested in 2015/2016 and 2016/2017 seasons were submitted to principal component analysis (PCA) and a clear group difference was observed (Figure 3). The principal components 1 and $2\left(\mathrm{PC}_{1}\right.$ and $\left.\mathrm{PC}_{2}\right)$ represented $99 \%$ of the explained variance and the $\mathrm{PC}_{1}$ was responsible for $92 \%$ and the $\mathrm{PC}_{2}$ for $7 \%$ of that (Figure 3). Fruit harvested in 2015/2016 grouped on the right hand side of the $\mathrm{PC}_{1}$ and fruit harvested in 2016/2017 on the left hand side quadrant with clear group segregation. According to Wang et al. (1991), one of the main factors that affect the performance of prediction models are samples coming from different batches. Regarding NIRS involving fresh fruit, this factor is probably the most important as fruit are matrixes subjected to variability within the plant (age, load, position, light, etc.), variability within orchards (soils type, nutrition, and climatic conditions), maturity stages and seasonal variability (Peirs et al., 2002). The results previously reported regarding the problems involving DM content prediction in 'Palmer' mangoes (Figure 1A and 2A) coming from different batches are in agreement with Wang et al. (1991) and Peirs et al. (2002).

Finally, fruit were harvest and prior the cold storage the maturity stage was predicted using the new PLS model. To sort the fruit into two maturity stages based on DM content 272 (150 g.kg ${ }^{-1}$ and 110 g.kg $\left.{ }^{-1}\right)$ the RMSEP value of 12.6 g. $\mathrm{kg}^{-1}$ was added and subtracted from the target DM contents. Therefore, the fruit were sorted in the range of 137.4 to $162.6{\mathrm{~g} . \mathrm{kg}^{-1}}^{\text {for }}$ the $150 \mathrm{~g} \cdot \mathrm{kg}^{-1} \mathrm{DM}$ content and in the range of 97.4 to $122.6 \mathrm{~g} \cdot \mathrm{kg}^{-1}$ for the $110 \mathrm{~g} \cdot \mathrm{kg}^{-1} \mathrm{DM}$ content. It is worth to mention that only $15.35 \%$ of the fruit were classified as $150{\mathrm{~g} . \mathrm{kg}^{-1} \mathrm{DM}}^{\mathrm{D}}$ and $16.28 \%$ with 110 g.kg ${ }^{-1}$ DM (Table 1), what represented a fruit loss of $84.65 \%$ and 83.72

$277 \%$, respectively. These results highlight the importance of using portable NIR spectrometer to 278 sort fruit when they are still in the fields as only those with the established DM content and/or 
279

280

281

282

283

284

285

286

287

288

289

290

291

292

293

294

295

296

297

298

299

300

other quality parameter would be harvested, and transported to the packing house, a vantage already reported by Subedi et al. (2007) for other mango cultivars.

\subsection{Cold storage}

\subsubsection{Respiratory activity}

The respiratory activity $\left(\mathrm{mg} \cdot \mathrm{CO}_{2} \cdot \mathrm{kg}^{-1} \cdot \mathrm{h}^{-1}\right)$ of 'Palmer' mangoes from both maturity stages was not significant different during cold storage and after transfer to ambient (Figure 4). During cold storage the respiratory activity varied greatly for fruit from both maturity stages, and it was not observed a climacteric peak as typically reported in mangoes (Kader, 2003; Chitarra \& Chitarra, 2005; Paull \& Duarte, 2011). Teixeira \& Durigan (2011) also did not observed the climacteric peak during 'Palmer' mango storage at $12.8^{\circ} \mathrm{C}$ for 28 days under controlled atmosphere $(\mathrm{CA})$, and the respiration rate $\left(21 \mathrm{kPa} \mathrm{O}_{2}\right)$ was similar to the fruit with 150 g.kg-1 and 110 g.kg-1 DM (Figure 4).

When fruit of both maturity stages were transfer to ambient the respiration rate significantly increased from $6.72^{ \pm} 1.50 \mathrm{mg} \cdot \mathrm{CO}_{2} \cdot \mathrm{kg}^{-1} \cdot \mathrm{h}^{-1}$ to and $8.56^{ \pm} 0.67 \mathrm{mg} \cdot \mathrm{CO}_{2} \cdot \mathrm{kg}^{-1} \cdot \mathrm{h}^{-1}$ (Figure 4). Teixeira \& Durigan (2011) also reported increments in respiration rate of 'Palmer' mangoes when fruit were transfer to ambient after cold storage. However, the respiration rates reported by Teixeira \& Durigan (2011) and Teixeira et al. (2018) were much higher than our results as these authors used immature mangoes and it might have affected the physiological activity (Award, 1993). In addition, the high fresh weight loss (Figure 5) might have affected the respiration and the other quality parameters (Table 2).

\subsubsection{Fresh weight loss}


The fresh weight loss (FWL) constantly increased during the cold storage period without significant differences between the maturity stages (Figure 5).

FWL reached $9.3 \%$ and $11.1 \%$ for fruit with $150 \mathrm{~g} \cdot \mathrm{kg}^{-1}$ and $110 \mathrm{~g} \cdot \mathrm{kg}^{-1} \mathrm{DM}$ on the 16

304

305

day of cold storage, respectively (Figure 5). Although any significant difference was observed between maturity stages, numerically the FWL of the fruit with 110 g. $\mathrm{kg}^{-1} \mathrm{DM}$ was superior then with 150 g.kg ${ }^{-1}$ DM (Figure 5). This difference is an indicative that fruit with $110 \mathrm{~g} \cdot \mathrm{kg}^{-1}$ DM were more immature as cuticle deposition takes place on more mature fruit and this process reduce moisture loss (Lashbrooke et al., 2014). Pantastico et al. (1979) reported that FWL commonly reach $14 \%$ during mango cold storage and losses over $5.0 \%$ can compromise fruit quality. If a FWL of $5.0 \%$ were considered as a threshold value, fruit with 110 g.kg ${ }^{-1} \mathrm{DM}$ would have had a shelf-life of only 4 days and fruit with $150 \mathrm{~g} \cdot \mathrm{kg}^{-1} \mathrm{DM}$ a shelf-life of 8 days (Figure 5). There results highlight the advantage of sorting more mature fruit for long term storage.

\subsubsection{Physico-chemical parameters}

The physico-chemical parameters determined during the cold storage for the 'Palmer' mangoes of the two maturity stages $\left(150 \mathrm{~g} \cdot \mathrm{kg}^{-1}\right.$ and $\left.110 \mathrm{~g} \cdot \mathrm{kg}^{-1} \mathrm{DM}\right)$ can be seen at Table 3 .

Regarding the colour parameters, it was not observed significant differences between maturity stages for $\mathrm{a}^{*}$ and hue angle $\left({ }^{\circ} \mathrm{h}\right)$, but significant differences were observed for luminosity (L*), b*, and chromaticity (Chroma*), Table 3. 'Palmer' mangoes with $110 \mathrm{~g} \cdot \mathrm{kg}^{-1}$ DM presented fruit with dark skins colour $\left(\mathrm{L}^{*}=38.68\right)$, with more blue $\left(\mathrm{b}^{*}=13.08\right)$ blush and saturation $($ chroma $=39.48)$ than fruit with 150 g.kg-1 DM $\left(\mathrm{L}^{*}=36.55, \mathrm{~b}^{*}=11.39\right.$, and chroma $=37.41)$. Although the magnitude of the differences were small, it is possible to state that fruit with 110 g.kg ${ }^{-1}$ DM were more immature than fruit with 150 g.kg-1 DM. Colour has long been used as a maturity index in mangoes (Malevski et al., 1977) and maturity stages can 
actually be predicted by using CIE colour parameters (Jha et al., 2007). Therefore, the use of a portable NIR spectrometer to sort 'Palmer' mangoes according to DM content indeed resulted in differences in maturity. On the other hand, all colour parameters did not change during cold storage and it was not observed significant interactions between maturity stages and withdraws (Table 3). Possibility during cold storage the low temperatures might have affected 'Palmer' mangoes colour changes as 'Kensington Pride' mango carotenoid synthesis was reduced under temperatures storage (O’Hare, 1995), similar to other mango varieties (Thompson, 1971; Medlicott et al., 1986). In addition, the elevate FWL lead the fruit to become withered and dehydrated after 14 days of cold storage, and the metabolic processes might have been affected by the losses (Wills et al., 1998).

The differences in maturity stages can also be observed as SSC and DM (Table 3). As fruit were deliberated sorted based on DM content using the PLS model, a significant difference was observed for this parameter, but the reference results were lower than the established DM content for both maturity stages, which means that the fruit with $110 \mathrm{~g} \cdot \mathrm{kg}^{-1}$ DM actually have 122.9 g. $\mathrm{kg}^{-1}$ and fruit with $150 \mathrm{~g} \cdot \mathrm{kg}^{-1} \mathrm{DM}$ have $134.4 \mathrm{~g} \cdot \mathrm{kg}^{-1}$ (Table 3). The SSC was also higher in fruit with 150 g. $\mathrm{kg}^{-1} \mathrm{DM}(7.92 \%)$ in relation to fruit with $110 \mathrm{~g} \cdot \mathrm{kg}^{-1}$ DM (7.39\%), but the other quality parameters (TA, $\mathrm{pH}$, ration, vitamin $\mathrm{C}$ content, and firmness) did not present significant differences (Table 3). Again by using NIRS was possible to sort fruit into two maturity stages with distinct quality characteristics.

During cold storage it was not observed any significant interaction between maturity stages and withdraws for all physic-chemical parameters (Table 3). However, it was observed significant differences for $\mathrm{pH}, \mathrm{SSC}$, TA, and vitamin $\mathrm{C}$ (Table 3). $\mathrm{pH}$ values reduced during cold storage and TA content increased (Table 3). The modifications are not in agreement with what is commonly described during mango fruit ripening as normally it is reported increases in $\mathrm{pH}$ and reductions in TA contents (Medlicott et al., 1986), including for 'Palmer' mangoes 
(Megale, 2002). O’Hare (1995), studying the effect of storage temperatures in 'Kensington

Pride' mangoes reported that at $13{ }^{\circ} \mathrm{C}$ the TA content were very high even after 20 days of storage. Melo Neto et al. (1999) also observed high TA content in 'Palmer' mangoes after 28 days of storage at $12{ }^{\circ} \mathrm{C}$. Therefore, the cold storage might have affected the ripening process and consequently organic acids retention, including the ascorbic acid (vitamin C), Table 3.

The SSC increased during cold storage from $6.2 \%$ on the first day to $9.9 \%$ on the 14 day (Table 3). In general during mango storage is reported an increase in SSC due to starch degradation (Khader, 1992; Mitcham \& McDonald, 1992). The observed SSC of $9.9 \%$ was not high enough as the ideal SSC for mango ranges from $10 \%$ (Medlicott et al., 1988) to 13 $\%$, and even higher values of $18.5 \%$ (Corrêa, 1992). According to Sañudo et al. (1997), by the time of 'Tommy Atkins' mango harvest aiming fruit export the SSC might range from $7 \%$ to $8 \%$, and Makani (2009) stated that a SSC of $13.5 \%$ as a threshold content for consumers to accept 'Tommy Atkins' mangoes. Possibly as the reference DM content, mainly for the 150 g.kg ${ }^{-1}$ DM maturity stage, was lower than was expected $\left(134.4{\mathrm{~g} . \mathrm{kg}^{-1}}^{-1}\right.$, the starch hydrolyses was not sufficient to warrantee a recommended SSC. Therefore, it is imperative a continuous development of the DM prediction model aiming improve robustness and accuracy in order to get results as close as possible to the target values.

\subsection{Ambient storage}

After cold storage the 'Palmer' mango fruit were transfer to ambient conditions $\left(21.6+4.2{ }^{\circ} \mathrm{C}\right.$ and $\left.67.6+4.5 \% \mathrm{HR}\right)$ for 7 days simulating fruit commercialization (Table 4). In ambient, fruit from both maturity stages lost more moisture and the FWL reached $16.4 \%$ and $18.1 \%$ for fruit with $150 \mathrm{~g} \cdot \mathrm{kg}^{-1}$ and $110 \mathrm{~g} \cdot \mathrm{kg}^{-1}$, respectively (Table 4). Therefore, fruit were completely withered, dehydrated and with compromised appearance. 
The initial colour differences observed between maturity stages (Table 3) disappeared and any significant difference was observed (Table 4). Fruit presented normal colour

375 development with dark skins $\left(\mathrm{L}^{*}=35.90-37.43\right)$, higher saturation $($ chroma $=36.74-$ $38.14)$, and with a typical 'Palmer' purple skin colour $\left({ }^{\circ} \mathrm{h}=266.71-274.08\right)$, Table 4. Colour changes were accelerated at ambient similar to previous reports on 'Palmer' mango cold storage (Melo Neto et al., 1999; Jeronimo \& Kanesiro, 2000).

The differences in terms of DM content also disappeared in ambient and the only observed significant difference was related to TA (Table 4). The DM content increased in both maturity stages and reached 130.1 and 143.0 g.kg-1 for fruit with 150 g. $\mathrm{kg}^{-1}$ and 110 g. $\mathrm{kg}^{-1}$, respectively (Table 4). DM content might have increased as a result of the fresh weight loss (FWL). However, only the fruit with 150 g.kg-1 $\mathrm{DM}$ content get close to the recommendation stated by Walsh et al. (2004), which means, 140 g.kg-1 but Walsh (2016) recommended higher DM contents $\left(150 \mathrm{~g} \cdot \mathrm{kg}^{-1}\right)$.

Starch hydrolysis might have affected the SSC which increase to $11.47-11.61 \%$ in fruit with 150 g.kg-1 and 110 g. $\mathrm{kg}^{-1}$, respectively (Table 4). These values are much closer to the range of $10-13 \%$ recommended by Medlicott et al. (1988). However, lower than what Makani (2009) stated as a threshold content for consumers to acceptance (13.5\%), and lower than Teixeira \& Durigan (2011) reported for mature 'Palmer' mangoes (14.2\%). On the other hand, the significant differences in TA content might indicate that fruit with $110 \mathrm{~g}^{\mathrm{kg}} \mathrm{g}^{-1} \mathrm{DM}$ (10.2 g. $\left.\mathrm{kg}^{-1}\right)$ as less mature then fruit with $150 \mathrm{~g} \cdot \mathrm{kg}^{-1} \mathrm{DM}\left(7.6 \mathrm{~g} \cdot \mathrm{kg}^{-1}\right)$ because TA contents generally reduce during mango ripening (Jeronimo \& Kanesiro, 2000; Paull \& Duarte, 2011).

\subsection{Sensorial evaluation}

The untrained panel was able to differentiate the external and internal appearance of the 'Palmer' mango from both maturity stages (Figure 6). 

for external or for internal appearance during cold storage (0, 7, and 14 days) and after transfer to ambient (21 day), Figure 6B. The more advanced ripening stage in the fruit with 150 g. $\mathrm{kg}^{-1} \mathrm{DM}$ was more evident when the panelist evaluated the internal appearance at 7 days in the ambient as the pulp colour turned more yellow and the score 8 "like very much" was attributed to the fruit. On the other hand, for the fruit with $110 \mathrm{~g} \cdot \mathrm{kg}^{-1} \mathrm{DM}$, the panelist 403 attribute a score 5 "neither like nor dislike" (Figure 6A).

404

405

\section{Conclusion}

It was not possible to predict dry matter (DM) content of 'Palmer' mangoes harvest in 2016/2017 season using the PLS model developed in 2015/2016 (Santos Neto et al., 2017), and a new model was developed (RMSE $E_{C}$ of $10 \mathrm{~g} \cdot \mathrm{kg}^{-1}, \mathrm{RMSE}_{\mathrm{cv}}$ of $10.5 \mathrm{~g} \cdot \mathrm{kg}^{-1}, \mathrm{R}_{\mathrm{c}}^{2}$ of 0.77 , and $\mathrm{R}_{\mathrm{P}}^{2}$ of 0.75 ). With the new model was possible to sort 'Palmer' mangoes into two maturity stages $\left(150 \mathrm{~g} \cdot \mathrm{kg}^{-1}\right.$ and $\left.110 \mathrm{~g} \cdot \mathrm{kg}^{-1}\right)$ which resulted in quality differences mainly in relation to DM and SSC. Sensorialy fruit with 150 g. $\mathrm{kg}^{-1} \mathrm{DM}$ content were better evaluated then fruit with 110 g. $\mathrm{kg}^{-1}$, and scores of 8 "like very much" for internal appearance and 7 "like moderately", for external appearance were attributed. The elevated fresh weight loss (FLW) observed during cold storage affected fruit quality of fruit from both maturity stages (150 g.kg ${ }^{-1}$ and 110 g. $\mathrm{kg}^{-1}$ ). Finally, portable VIS/NIR spectrometer can be used to sort fruit according to maturity stages based on DM content and this classification affect fruit quality during cold storage as fruit with higher DM (150 g. $\left.\mathrm{kg}^{-1}\right)$ presented better quality than fruit with lower DM (110 g.kg-1). 
421

422

423

424

425

426

427

428

429

430

431

432

433

434

435

436

437

438

439

440

441

442

443

The authors would like to thank Fundação de Amparo à Pesquisa do Estado de São Paulo (FAPESP) for funding this research (proc. 2015/03451-9) and providing the Doctorate fellowship (proc. 2015/25631-9). The authors also thank Tecnal equipamentos Científicos for lending the F-750 spectrometer, and Hermes and Rodrigo Pinhatti for providing the fruit.

\section{References}

Awad, M. (1993). Fisiologia pós-colheita de frutos. São Paulo: Nobel.

Anderson, N.T., Subedi, P.P., Walsh, K.B. (2017). Manipulation of mango fruit dry matter content to improve eating quality. Scientia Horticulturae, 226, 316-321.

Abbott, J.A. (1999). Quality measurement of fruits and vegetables. Postharvest Biology and Technology, 15, 207-225.

AOAC. (1997). Official methods of analysis of the Association of Official Analytical Chemists. (16 ${ }^{\text {th }}$ ed.). Arlington: Patrícia Cuniff.

Betemps, D.L., Fachinello, J.C., Galarça, S.P. (2011). Espectroscopia do visível e infravermelho próximo (VIS/NIR) na avaliação da qualidade de mangas Tommy Atkins. Revista Brasileira de Fruticultura, 33, 306-313.

Bleinroth, E.W., Zuchini, A.G., Pompeo, R.M. (1976). Determinação das características físicas e mecânicas de variedade de abacate e sua conservação pelo frio. Coletânea ITA, 7, 2981.

Brecht, J.K., \& Yahia, E.M. (2009). Postharvest physiology. In: Litz, R.E. (Ed.), The Mango 2nd Edition: Botany, Production and Uses (pp.484-528). Wallingford: CAB International.

Chitarra, M.I.F., \& Chitarra, A.B. (2005). Pós-colheita de frutas e hortaliças: fisiologia e manuseio. (2nd ed.). Lavras: UFLA. 
444 Corrêa, G.C. (1992). Efeito da época de oferta e classificação, na qualidade de frutos de 445 mangueira (Mangifera indica, L. cv. Tommy Atkins). Master Theses. Lavras: Universidade 446 Federal de Lavras.

447 Delwiche, S.R., Mekwatanakarn. W., Wang. C.Y. (2008). Soluble solids and simple sugars 448 measurement in intact mango using near infrared spectroscopy. HortTechnology, 18, 410-416. 449 Dutcosky, S.D. (2013). Análise sensorial de alimentos. Curitiba: PUCPRESS.

450 Golic, M., \& Walsh, K.B. (2006). Robustness of calibration models based on near infrared 451 spectroscopy for the in-line grading of stone fruit for total soluble solids content. Analytica 452 Chimica Acta, 555, 286-291.

453 Jenonimo, E.M., \& Kanesiro, M.A.B. (2000). Efeito da associação de armazenamento sob 454 refrigeração e atmosfera modificada na qualidade de mangas 'Palmer'. Revista Brasileira de 455 Fruticultura, 22,237-243.

456 Jha, S. N., Jaiswal, P., Narsaiah, K., Gupta, M., Bhardwaj, R., Singh, A. K. (2012). Non457 destructive prediction of sweetness of intact mango using near infrared spectroscopy. Scientia 458 Horticulturae, 138, 171-175.

459 Jha, S.N., Chopra, S., Kingsly, A.R.P. (2007). Modeling of colour values for nondestructive 460 evaluation of maturity of mango. Journal of Food Engineering, 78, 22-26.

461 Jha, S.N., Narsaiah, K., Jaiswal, P., Bhardwaj, R., Gupta, M., Kumar, R., Sharma, R. (2014). 462 Nondestructive prediction of maturity of mango using near infrared spectroscopy. Journal of 463 Food Engineering, 124, 152-157.

464 Kader, A.A. (2003). Postharvest biology and technology: an overview. In: Kader, A.A. (Ed.). 465 Postharvest technology of horticultural crops (pp.39-47). Davis: University of California: 466 Division of Agriculture and Natural Resources Publication. 
467 Khader, S.E.S.A. (1992). Effect of gibberellic acid and vapor gard on ripening, amylase and 468 peroxidase activities and quality of mango fruits during storage. Journal of Horticultural 469 Science, 67, 855-860.

470 Lashbrooke, J., Costa, F., Aharoni, A. (2014). Making the surface of fresh fruit: synthesis, assembly and role of the cuticular layer. In: Nath, P., Bauzayen, M., Matto, A.K., Pech, J.C. 472 (Eds.). Fruit ripening, physiology, signaling and genomics (pp.81-98). Oxforshire: CABI 473 International.

Mahayothee, B., Leitenberger, M., Neidhart, S., Mühlbauer, W., Carle, R. (2004). 475 Nondestructive determination of maturity of Thai mangoes by near-infrared spectroscopy. 476 Acta Horticulturae, 645, 581-588.

477 Makani, O.A. (2009). Mango quality survey and sensory evaluation of mango (Mangifera 478 indica L.) cultivars. Master Thesis. Gatton: University of Queensland. Malevski, Y., Gomez Brito, L., Peleg, M., Silberg, M. (1977). External color as maturity 480 index of mango. Journal of Food Science, 42, 1316-1318.

481 Marques, E.J.N., Freitas, S.T., Pimentel, M.F., Pasquini, C. (2016). Rapid and non-destructive 482 determination of quality parameters in the 'Tommy Atkins' mango using a novel handheld near infrared spectrometer. Food Chemistry, 197, 1207-1214. McGuire, R.G. (1992). Reporting of objective color measurements. HortScience, 27, 12541555.

486 Medlicott, A.P., Bhogol, M., Reynolds, S.B. (1986). Changes in peel pigmentation during 487 ripening of mango fruit (Mangifera indica var. Tommy Atkins). Annals of Applied Biology, $109,651-656$.

489 Medlicott, A.P., Reynalds, S.B., New, S.W., Thompson, A.K. (1988). Harvest maturity 490 effects on mango fruit ripening. Tropical Agriculture, 65, 153-157. 
491

492

493

494

495

496

497

498

499

500

501

502

503

504

505

506

507

508

509

510

511

512

513

514

515

Megale, J. (2002). Influência do estádio de maturação e da condição de armazenagem em parâmetros sensoriais, químicos e microbiológicos de manga, cultivar Palmer, semiprocessada. Master Thesis. Campinas: Universidade Estadual de Campinas.

Melo Neto, M.L., Christoffoleti, P.J., Sigrist, J.M.M., Alves, R.M.V. (1999). Utilização de embalagens plásticas e refrigeração na conservação de manga (Mangifera indica L.) cv. Palmer. Revista Brasileira de Fruticultura, 21, 160-165.

Miltra, S.K., \& Baldwin, E.A. (1997). Mango, In: Miltra, S.K. (Ed.). Postharvest physiology and storage of tropical and subtropical fruit. Wallingford: CAB International.

Mitcham, E.J., \& McDonald, R.E. (1992). Cell wall modification during ripening of 'Keitt' and 'Tommy Atkins' mango fruit. Journal of the American Society for Horticultural Sciences, 117, 919-924.

Mohammed, M., \& Brecht, J.K. (2002). Reduction of chilling injury in 'Tommy Atkins' mangoes during ripening. Scientia Horticulturae, 95, 297-308.

Nordey, T., Joas, J., Davrieux, F., Chillet, M., Léchaudel, M. (2017). Robust NIRS models for non-destructive prediction of mango internal quality. Scientia Horticulturae, 216, 51-57.

Nicolai, B.M., Beullens, K., Bobelyn, E., Peirs, A., Saeys, W., Theron, K.I., Lammertyna, J. (2007). Nondestructive measurement of fruit and vegetable quality by means of NIR spectroscopy: A review. Postharvest Biology and Technology, 46, 99-118.

O'Hare, T.J. (1995). Effect of ripening temperature on quality and composition changes of mango (Mangifera indica L.) cv. Kensington. Australian Journal of Experimental Agriculture, 35, 259-263.

Pantastico, Er.B., Chattopadhyay, T.K., Subramanyam, H. (1979). Almacenamiento y operaciones comerciales de almacenaje. In: Pantastico, Er. B. (Ed.). Fisiologia de la postrecoleccion, manejo y utilizacion de frutas y hortalizas tropicales y subtropicales (pp.375-405). México: Compañía Editorial Continental, S. A. 
516

517

518

519

520

521

522

Pasquini, C. (2003). Near Infrared Spectroscopy: Fundamentals, Practical Aspects and Analytical Applications. Journal of the Brazilian Chemical Society, 14, 198-219.

Paull, R.E., \& Duarte, O. (2011). Tropical fruits, (2nd ed.). Wallingford: CAB International.

Peirs, A., Tirry, J., Verlinden, B., Darius, P., Nicolai, B.M. (2002). Effect of biological variability on the robustness of NIR-models for soluble solids content of apples. Postharvest Biology and Technology, 28, 269-280.

Rungpichayapichet, P., Mahayothee, B., Nagle, M., Khuwijitjaru, P., Müller, J. (2016). Robust NIRS models for non-destructive prediction of postharvest fruit ripeness and quality in mango. Postharvest Biology and Technology, 111, 31-40.

Santos Neto, J.P., Assis, M.W.D., Casagrande, I.P., Cunha Júnior, L.C., Teixeira, G.H.A. (2017). Determination of 'Palmer' mango maturity indices using portable near infrared (VISNIR) spectrometer. Postharvest Biology and Technology, 130, 75-80.

Sañudo, R., Bustillos, R.J.A., Garcia, L.P. de., Molina, E.B., Nuño, S.O., Angel, D.N. (1997). Manejo postcosecha del mango. México: EMEX.

Saranwong, S., Sornsrivichai, J., Kawano, S. (2001). Improvement of PLS calibration for Brix value and dry matter of mango using information from MLR calibration. Journal of Near Infrared Spectroscopy, 9, 287-295.

Saranwong, S., Sornsrivichai, J., Kawano, S. (2004). Prediction of ripe-stage eating quality of mango fruit from its harvest quality measured nondestructively by near infrared spectroscopy. Postharvest Biology and Technology, 31, 137-145.

SAS. (1999). SAS User's guide: statistics, ( $8^{\text {th }}$ ed.). Cary: SAS Institute Inc..

Schmilovitch, Z., Mizrach, A., Hoffman, A., Egozi, A., Fuchs, Y. (2000). Determination of mango physiological indices by near-infrared spectrometry. Postharvest Biology and Technology, 19, 245-252. 
540 Strohecker, R., \& Henning, H.M. (1967). Análises de vitaminas: métodos comprovados.

541 Madrid: Paz Montolvo.

542 Subedi, P.P., \& Walsh, K.B. (2011). Assessment of sugar and starch in intact banana and 543 mango fruit by swnirs spectroscopy. Postharvest Biology and Technology, 62, 238-245.

544 Subedi, P.P., Walsh, K.B., Owens, G. (2007). Prediction of mango eating quality at harvest 545 using short-wave near infrared spectrometry. Postharvest Biology and Technology, 43, 326546334.

547 Teixeira, G.H.A., \& Durigan, J.F. (2011). Storage of 'Palmer' mangoes in low-oxygen 548 atmospheres. Fruits, 66, 279-289.

549 Teixeira, G.H.A., Santos, L.O., Cunha Júnior, LC., Durigan, J.F. (2018). Increasing levels of 550 carbon dioxide $\left(\mathrm{CO}_{2}\right)$ associated with low-oxygen $\left(\mathrm{O}_{2}\right)$ do not affect the quality of 'Palmer' 551 mangoes during controlled atmosphere storage. Journal of Food Science and Technology, 55, $552 \quad 145-156$.

553 Thompson, A.K. (1971). The storage of mango fruits. Tropical Agriculture, 48, 63-70.

554 Valente, M., Leardi, R., Self, G., Luciano, G., Pain, J.P. (2009). Multivariate calibration of 555 mango firmness using vis/nirs spectroscopy and acoustic impulse method. Journal of Food 556 Engineering, 94, 7-13.

557 Walsh, K.B. (2016). Dry matter matters. <http://www.industry.mangoes.net.au/resource558 collection/2016/3/6/dry-matter-matters>. Accessed in March 2017.

559 Walsh, K.B., Golic, M., Greensill, C.V. (2004). Sorting of fruit using near infrared 560 spectroscopy: application to a range of fruit and vegetables for soluble solids and dry matter 561 content. Journal of Near Infrared Spectroscopy, 12, 141-148.

562 Walsh, K.B., \& Subedi, P.P. (2016). In-field monitoring of mango fruit dry matter for 563 maturity estimation. Acta Horticulturae, 1119, 273-278. 
564 Wang, Y., Veltkamp, D.J., Kowalski, B.R. (1991). Multivariate instrument standardization. 565 Analytical Chemistry, 63, 2750-2756.

566 Watkins, C., Harman, J. (1981). Use of penetrometer to measure flesh firmness of fruit. 567 Orchardist New Zealand, 54, 14-16.

568 Wills, R., McGlasson, B., Graham, D., Joyce, D. (1998). Postharvest: an introduction to the 569 physiology \& handling of fruit, vegetables \& ornamentals. Sydney: UNSW Press.

570 Yahia, E.M. (2011). Mango (Mangifera indica L.). In: Yahia, E.M. (Ed.). Postharvest biology 571 and technology of tropical and subtropical fruits, Volume 3: cocona to mango (pp.492-565). 572 Woodhead Publishing. 
576 Table 1 Descriptive statistics of the two 'Palmer' mangoes maturity stages established based

577 on dry matter (DM) content of fruit harvested in 2016/2017 season.

\begin{tabular}{lllllll}
\hline Maturity stage & Total & Sorted & Mean & Maximum & Minimum & SD $^{\mathbf{a}}$ \\
\hline $150 \mathrm{~g} \cdot \mathrm{kg}^{-1} \mathrm{DM}$ & 430 & 66 & 14.62 & 15.99 & 14.01 & 0.51 \\
$110 \mathrm{~g} \cdot \mathrm{kg}^{-1} \mathrm{DM}$ & 430 & 70 & 11.61 & 11.99 & 10.06 & 0.36 \\
\hline
\end{tabular}

$578 \quad{ }^{\mathrm{a}} \mathrm{SD}=$ standard deviation.

579

580 Table 2. Meteorological data of 2015/2016 and 2016/2017 mango harvest seasons of 581 Jaboticabal - SP.

\begin{tabular}{lccccccc}
\hline Season & $\begin{array}{c}\text { Pressure } \\
(\mathrm{hPa})\end{array}$ & $\begin{array}{c}\mathbf{T}_{\mathbf{m a x}} \\
\left({ }^{\circ} \mathrm{C}\right)\end{array}$ & $\begin{array}{c}\mathbf{T}_{\text {min }} \\
\left({ }^{\circ} \mathrm{C}\right)\end{array}$ & $\begin{array}{c}\mathbf{T}_{\text {mean }} \\
\left({ }^{\circ} \mathrm{C}\right)\end{array}$ & $\begin{array}{c}\text { RH } \\
(\%)\end{array}$ & $\begin{array}{c}\text { Precipitation } \\
(\mathrm{mm})\end{array}$ & $\begin{array}{c}\text { Sunlight } \\
(\mathrm{h})\end{array}$ \\
\hline $2015 / 2016$ & 942.50 & 30.89 & 18.87 & 23.82 & 72.62 & 192.30 & 201.19 \\
$\mathrm{SD}^{*}$ & 1.84 & 1.88 & 2.71 & 2.00 & 9.29 & 145.84 & 38.73 \\
$2016 / 2017$ & 942.15 & 30.83 & 17.62 & 23.20 & 68.41 & 116.31 & 231.47 \\
$\mathrm{SD}^{*}$ & 0.21 & 1.32 & 2.90 & 1.97 & 7.30 & 86.25 & 37.32 \\
\hline
\end{tabular}

*Standard deviation. 
584 Table 3. Physico-chemical quality parameters of 'Palmer' mangoes of two maturity stages $\left(150 \mathrm{~g}^{\mathrm{kg}} \mathrm{gg}^{-1}\right.$ and $\left.110 \mathrm{~g} \cdot \mathrm{kg}^{-1} \mathrm{DM}\right) \mathrm{stored}$ at $12.3^{ \pm} 0.4^{\circ} \mathrm{C}$ 585 and $69.9 \pm 4.1 \%$ RH for 14 days.

\begin{tabular}{|c|c|c|c|c|c|c|c|c|c|c|c|}
\hline Main effects & $\mathbf{L}^{*}$ & $a^{*}$ & $\mathbf{b}^{*}$ & Hue $^{a}$ & $\mathbf{C}^{\mathbf{b}}$ & pH & $\operatorname{SSC}(\%)^{\mathrm{c}}$ & $\mathbf{T A}^{\mathrm{d}}$ & SSC/TA & $\begin{array}{c}\text { Firmness } \\
(\mathbf{N})\end{array}$ & $\overline{D M}\left(\mathrm{~g}^{\prime} \mathrm{kg}^{-1}\right)^{\mathrm{e}}$ \\
\hline \multicolumn{12}{|l|}{ Maturity stages (M) } \\
\hline 110 g. $\mathrm{kg}^{-1} \mathrm{DM}$ & $38.68 \mathrm{a}$ & -4.41 & $13.08 \mathrm{a}$ & 264.45 & $39.48 \mathrm{a}$ & 2.92 & $7.39 \mathrm{~b}$ & 0.81 & 9.71 & 127.4 & $122.9 \mathrm{~b}$ \\
\hline 150 g.kg ${ }^{-1} \mathrm{DM}$ & $36.55 \mathrm{~b}$ & -1.83 & $11.39 \mathrm{~b}$ & 268.49 & $37.41 \mathrm{~b}$ & 2.99 & $7.92 \mathrm{a}$ & 0.73 & 12.48 & 124.2 & $134.4 \mathrm{a}$ \\
\hline F Test & $4.88^{*}$ & $3.37^{\mathrm{NS}}$ & $5.89 *$ & $3.15^{\mathrm{NS}}$ & $4.16^{*}$ & $3.81^{\mathrm{NS}}$ & $3.45^{*}$ & $4.19^{\mathrm{NS}}$ & $1.88^{\mathrm{NS}}$ & $0.48^{\mathrm{NS}}$ & $62.5^{*}$ \\
\hline \multicolumn{12}{|l|}{ Storage (S) } \\
\hline 0 & 37.93 & -3.74 & 12.74 & 265.51 & 38.66 & $3.25 \mathrm{a}$ & $6.22 \mathrm{c}$ & $0.64 \mathrm{~b}$ & 10.38 & 128.9 & 124.2 \\
\hline 7 & 37.52 & -2.36 & 12.35 & 267.80 & 38.59 & $3.28 \mathrm{a}$ & $6.85 \mathrm{~b}$ & $0.79 \mathrm{a}$ & 11.26 & 121.8 & 130.1 \\
\hline 14 & 37.20 & -3.02 & 11.44 & 266.49 & 37.89 & $2.35 \mathrm{~b}$ & $9.95 \mathrm{a}$ & $0.88 \mathrm{a}$ & 11.92 & 126.4 & 132.7 \\
\hline F Test & $0.16^{\mathrm{NS}}$ & $0.53^{\mathrm{NS}}$ & $0.67^{\mathrm{NS}}$ & $0.54^{\mathrm{NS}}$ & $0.18^{\mathrm{NS}}$ & $188.86^{* *}$ & $156.43^{* *}$ & $8.90^{* *}$ & $0.19^{\mathrm{NS}}$ & $0.98^{\mathrm{NS}}$ & $8.6^{\mathrm{NS}}$ \\
\hline \multicolumn{12}{|l|}{ Interaction } \\
\hline$M \times D$ & $0.80^{\mathrm{NS}}$ & $2.09^{\mathrm{NS}}$ & $2.53^{\mathrm{NS}}$ & $2.64^{\mathrm{NS}}$ & $0.79^{\mathrm{NS}}$ & $2.26^{\mathrm{NS}}$ & $0.07^{\mathrm{NS}}$ & $4.04^{\mathrm{NS}}$ & $1.74^{\mathrm{NS}}$ & $0.91^{\mathrm{NS}}$ & $0.44^{\mathrm{NS}}$ \\
\hline
\end{tabular}

$586 \mathrm{~L}^{*}=$ luminosity, ${ }^{\mathrm{a}}$ hue angle,${ }^{\mathrm{b}}$ chromaticity, ${ }^{\mathrm{c}}$ soluble solids content, ${ }^{\mathrm{d}}$ titratable acidity, ${ }^{\mathrm{e}}$ dry matter. Average values with the same letter within

587 the columns are not statistically different by Tukey's test $(\mathrm{p}<0.05)$. Values in the column without letter are not statistically different by Tukey's

588 test $(\mathrm{p}<0.05) . \mathrm{NS}=$ no significant. 


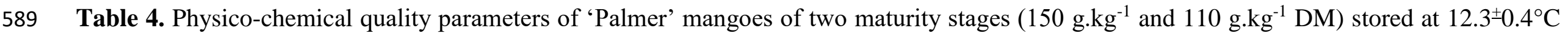
590 and $69.9 \pm 4.1 \% \mathrm{RH}$ for 14 days and seven days at ambient conditions $\left(21.6^{ \pm} 4.2^{\circ} \mathrm{C}\right.$ and $\left.67.6 \pm 4.5 \% \mathrm{UR}\right)$.

\begin{tabular}{|c|c|c|c|c|c|c|c|c|c|c|c|}
\hline Main effects & $\mathbf{L}^{*}$ & $a^{*}$ & $\mathbf{b}^{*}$ & Hue $^{a}$ & $\mathbf{C}^{\mathbf{b}}$ & pH & $\operatorname{SSC}(\%)^{\mathrm{c}}$ & $\mathbf{T A}^{\mathrm{d}}$ & SSC/TA & $\begin{array}{c}\text { Firmness( } \\
\mathbf{N})\end{array}$ & $\overline{D M}\left(\text { g.kg }^{-1}\right)^{\mathrm{e}}$ \\
\hline 110 g.kg ${ }^{-1} \mathrm{DM}$ & 37.43 & -2.78 & 11.71 & 266.71 & 38.14 & 2.42 & 11.47 & $1.02 \mathrm{a}$ & 11.92 & 57.25 & 130.1 \\
\hline 150 g.kg ${ }^{-1} \mathrm{DM}$ & 35.90 & 1.41 & 9.45 & 274.08 & 36.74 & 2.52 & 11.61 & $0.76 \mathrm{~b}$ & 15.84 & 73.55 & 143.0 \\
\hline Teste F & $0.29^{\mathrm{NS}}$ & $1.24^{\mathrm{NS}}$ & $0.84^{\mathrm{NS}}$ & $0.25^{\mathrm{NS}}$ & $0.99^{\mathrm{NS}}$ & $3.81^{\mathrm{NS}}$ & $0.05^{\mathrm{NS}}$ & $5.51 *$ & $2.46^{\mathrm{NS}}$ & $2.05^{\mathrm{NS}}$ & $0.56^{\mathrm{NS}}$ \\
\hline
\end{tabular}

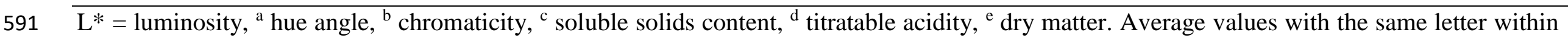

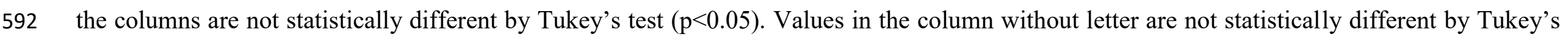

593 test $(\mathrm{p}<0.05)$. NS = no significant. 

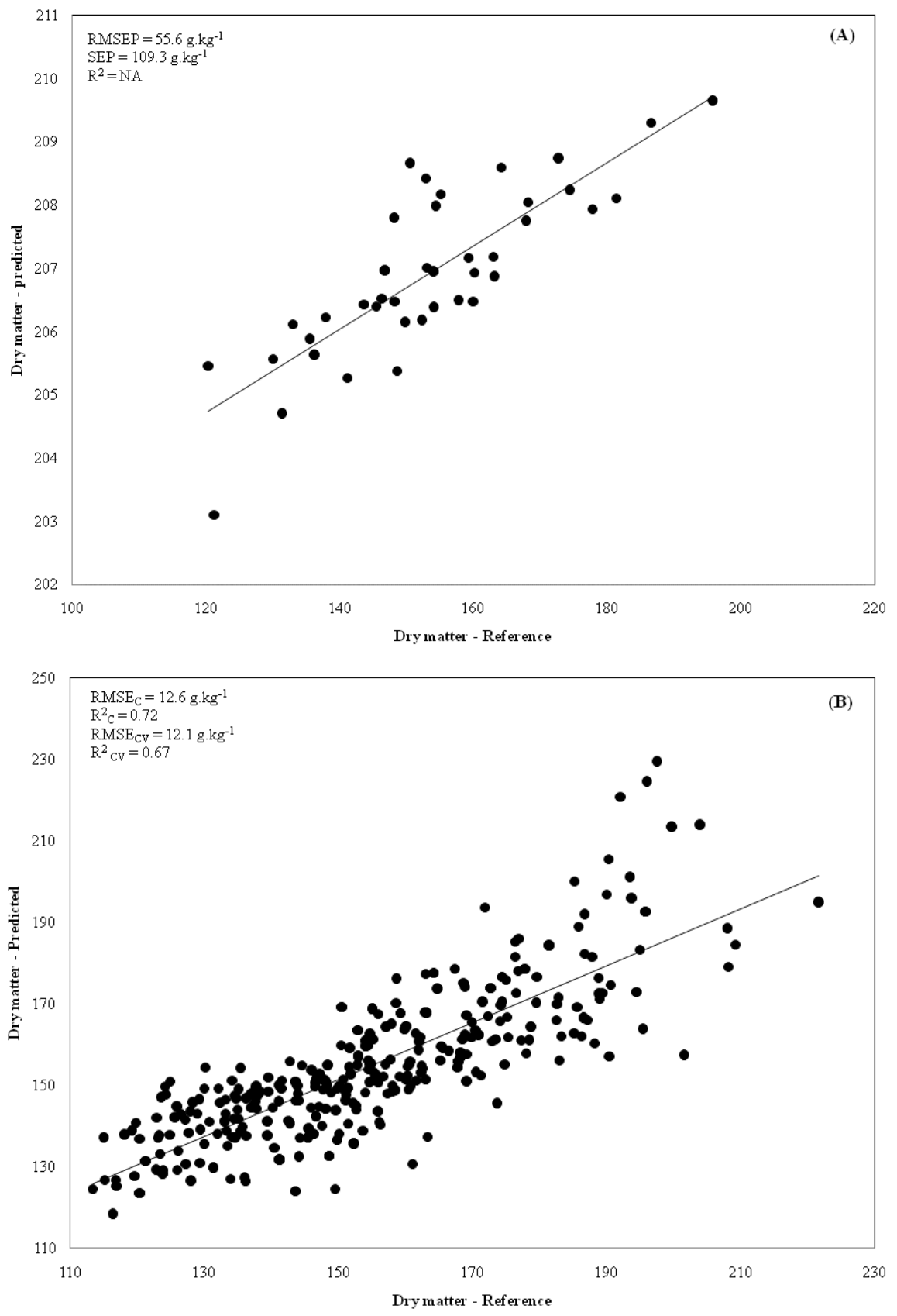

597 Figure 1. Dry matter prediction performance of the PLS model developed by Santos Neto et al. 598 (2017) using 'Palmer' mangoes from 2016/2017 (A). Predicted and reference DM content 599 obtained with the new PLS model by incorporating the NIR spectra from 2016/2017 harvest (B). 

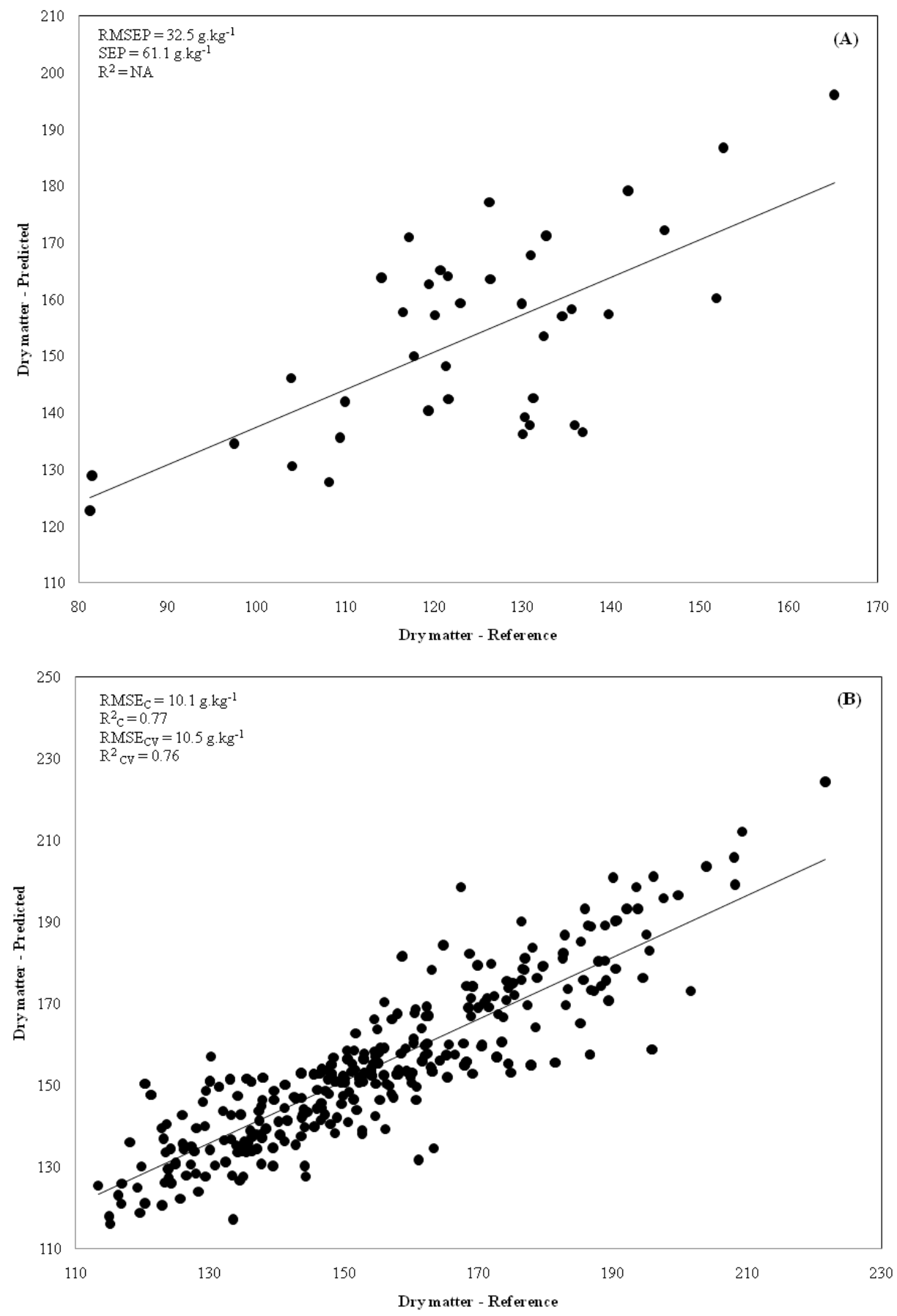

601

602 Figure 2. Dry matter prediction performance of the PLS model developed by incorporating the 603 NIR spectra from 2016/2017 (A). Predicted and reference DM content obtained with the new 604 PLS model by incorporating the NIR spectra from the second 2016/2017 harvest (B). 


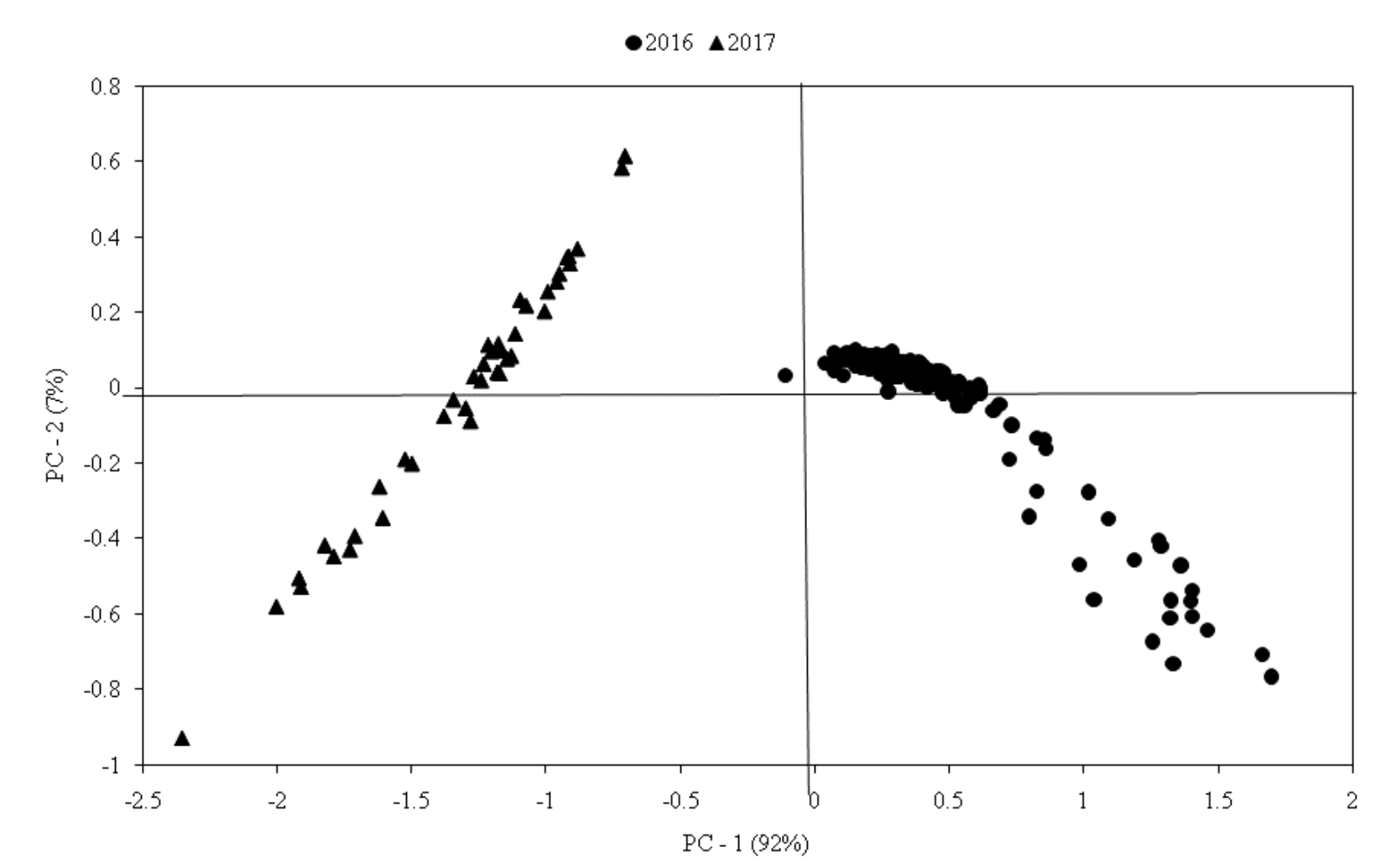

605

606

607 (699-981 nm) without pre-processing of intact 'Palmer' mangoes harvested in 2015/16 and 608 2016/17. 


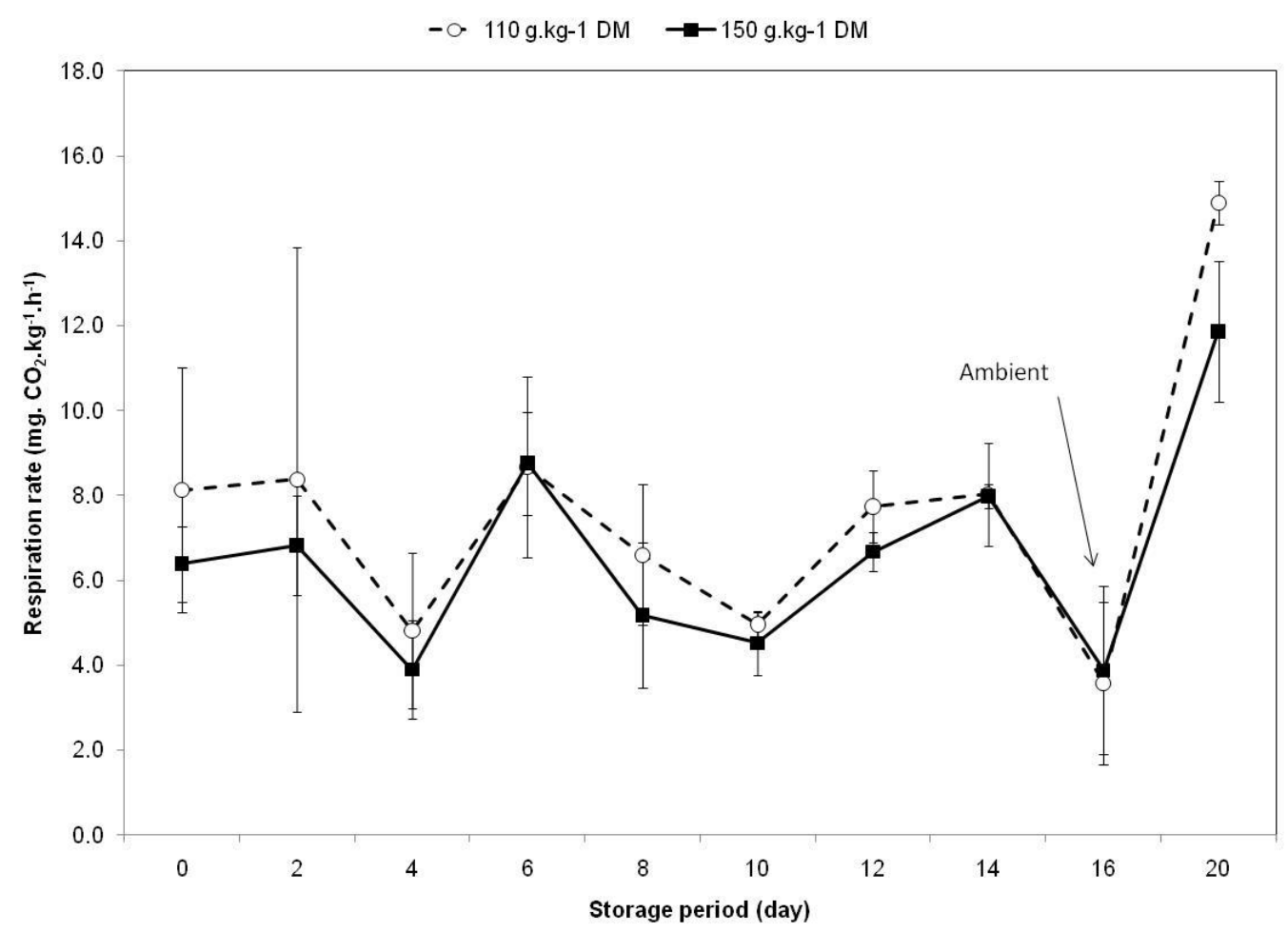

610

611 Figure 4. Respiratory activity $\left(\mathrm{mg} \cdot \mathrm{CO}_{2} \cdot \mathrm{kg}^{-1} \cdot \mathrm{h}^{-1}\right)$ of 'Palmer mangoes sorted into two maturity 612 stages $\left(150\right.$ g. $\mathrm{kg}^{-1}$ and 110 g.kg-1) during cold storage $\left(12.3 \pm 0.4{ }^{\circ} \mathrm{C}\right.$ and $\left.69.9 \pm 4.1 \% \mathrm{RH}\right)$ for 61314 days and under ambient conditions $\left(21.6 \pm 4.2{ }^{\circ} \mathrm{C}\right.$ and $\left.67.6 \pm 4.5 \% \mathrm{RH}\right)$ for 7 days. The 614 vertical bars indicate standard deviations of three repetitions. 


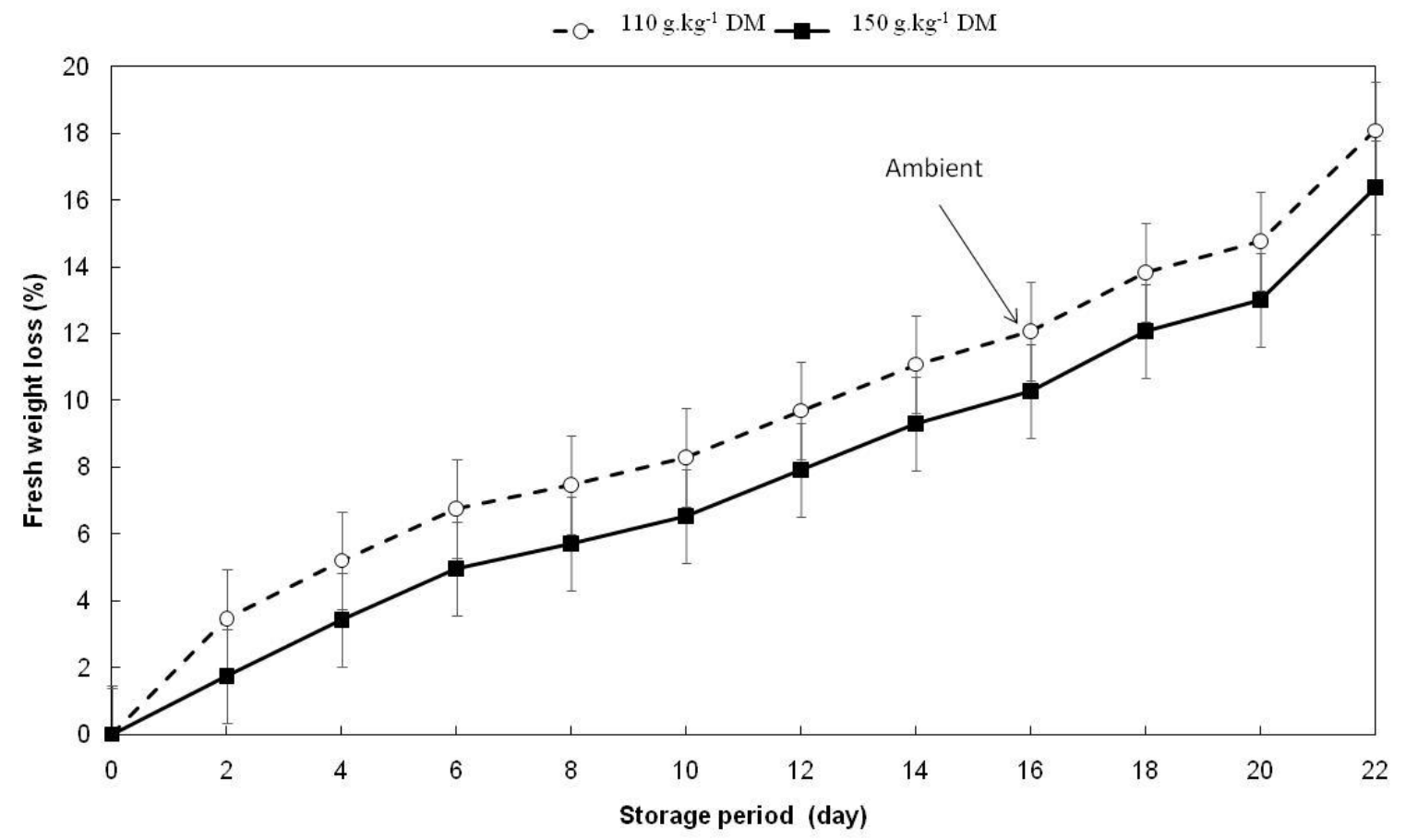

618 Figure 5. The fresh weigh loss (FWL - \%) of 'Palmer' mangoes sorted into two maturity stages

619 (150 g. $\mathrm{kg}^{-1}$ and 110 g.kg $\left.{ }^{-1}\right)$ during cold storage $\left(12.3 \pm 0.4{ }^{\circ} \mathrm{C}\right.$ and $\left.69.9 \pm 4.1 \% \mathrm{RH}\right)$ for 14 days 620 and under ambient conditions $\left(21.6 \pm 4.2^{\circ} \mathrm{C}\right.$ and $\left.67.6 \pm 4.5 \% \mathrm{RH}\right)$ for 7 days. The vertical bars 621 indicate standard deviations of three repetitions. 

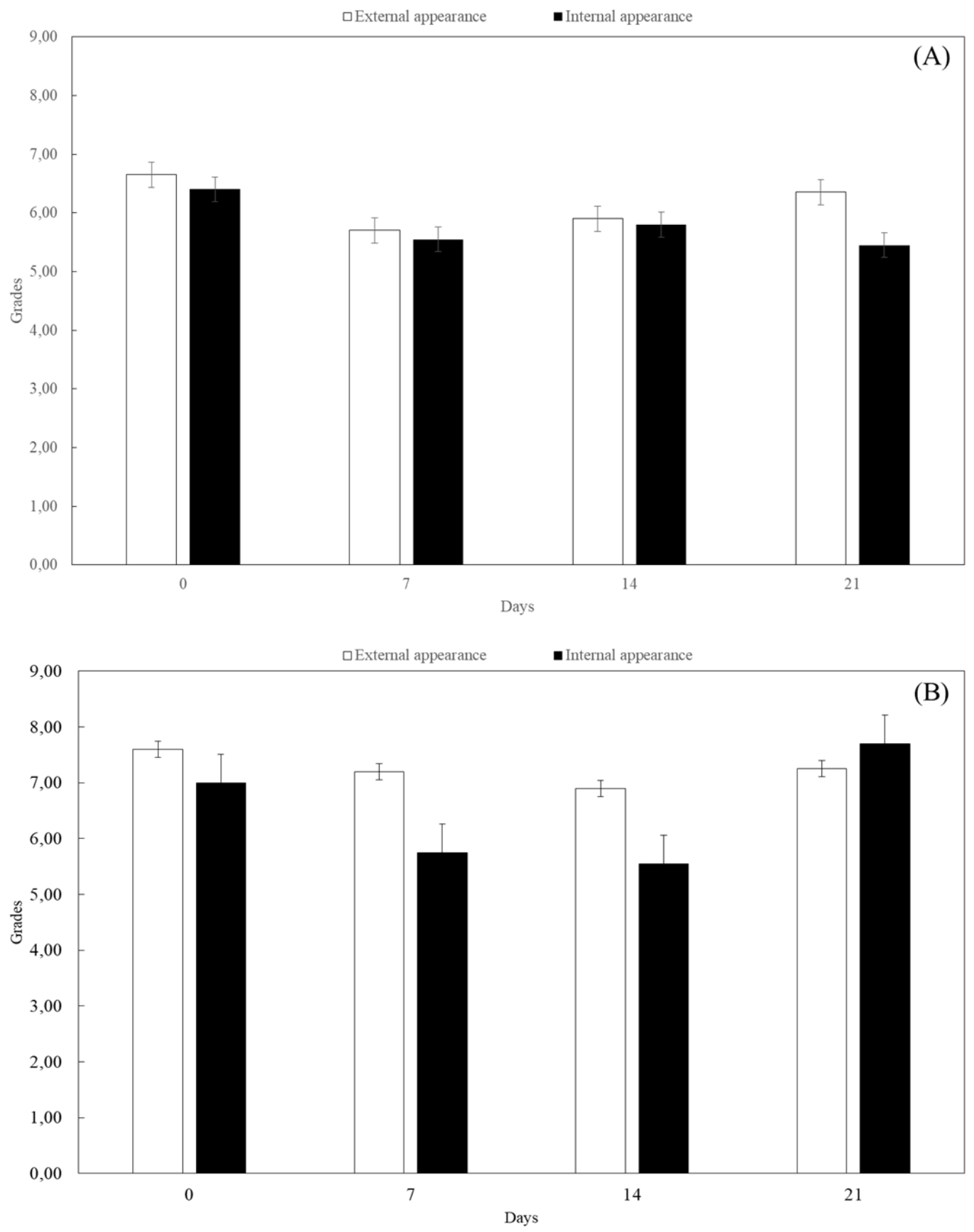

624 Figure 6. Sensorial evaluation of 'Palmer' mangoes sorted base on dry matter content (A) 110 625 g.kg ${ }^{-1}$ and (B) $150 \mathrm{~g} . \mathrm{kg}^{-1}$, during in cold storage $\left(12.3 \pm 0.4{ }^{\circ} \mathrm{C}\right.$ and $\left.69.9 \pm 4.1 \% \mathrm{RH}\right)$ for 14 days 626 and under ambient conditions $\left(21.6 \pm 4.2{ }^{\circ} \mathrm{C}\right.$ and $\left.67.6 \pm 4.5 \% \mathrm{RH}\right)$ for 7 days. The vertical bars 627 indicate standard deviations of 20 repetitions. 